\title{
5' Nucleotidase Family
}

National Cancer Institute

\section{Source}

National Cancer Institute. $5^{\prime}$ Nucleotidase Family. NCI Thesaurus. Code C19637.

A class of enzymes present in various org ans and in many cells that catalyze the hydrolysis of a 5'-ribonucleotide to a ribonucleoside and orthophosphate in the presence of water. Serum 5'-N'T ase is measured as an indicator of liver damage resulting primarily from interference with the secretion of bile. Serum 5'-N'T ase is not as sensitive as some other enzymes (for example, ALP, AST, and ALT) to liver damage, but it is a more liverspecific enzyme. The level of this enzyme parallels alkaline phosphatase (ALP). It is used mostly to differentiate elevations in the above enzymes due to liver damage from damage to skeletal muscle. 